\title{
Overcoming Poverty through Social Entrepreneurship: A Conceptual Paper
}

 \\ ${ }^{1}$ Universiti Sultan ZainalAbidin, Gong Badak Campus, Terengganu, Malaysia \\ ${ }^{2}$ Universiti Putra Malaysia, Selangor, Malaysia \\ ${ }^{3}$ Universiti Malaysia Kelantan, Malaysia \\ Correspondence: Wan Norhayate Wan Daud, Universiti Sultan Zainal Abidin, Gong Badak Campus, 21300 \\ Kuala Terengganu, Terengganu, Malaysia. Tel: 609-012-981-8045. E-mail: wnhayate@ unisza.edu.my
}

Received: May 3, 2014

Accepted: May 27, 2014

Online Published: June 25, 2014

doi:10.5539/ibr.v7n7p183

URL: http://dx.doi.org/10.5539/ibr.v7n7p183

\begin{abstract}
This paper aims to propose a conceptual framework to study the relationship between social entrepreneurship and organizational effectiveness. It also explains various theories of change that social entrepreneurs have pursued in overcoming urban poverty in the country. The study will utilize qualitative methods to collect primary data from social entrepreneurship organization in the main cities in Malaysia. The data from the interview will be evaluated to determine how organizational effectiveness can help social entrepreneurship to overcome urban poverty. Although no single social entrepreneurial venture had put a huge dent in poverty, there certainly have been many initiatives that have notable stories to tell about how they have helps poor people. Many researches are now needed to document which "social" returns on investments and to determine the strategies that lead to the best returns. The findings could benefit not only individual social entrepreneurs but also public, policy maker and firms by clarifying how much social entrepreneurship could be relied upon to help alleviate poverty compared to government and business initiatives. Therefore the findings of this research are expected to provide the view of how social entrepreneurship can give impact to urban poverty in the selected area through organizational effectiveness.
\end{abstract}

Keywords: urban poverty, social entrepreneurship, organizational effectiveness, Malaysia

\section{Introduction}

Poverty is understood as the deprivation of basic capabilities that provide a person with the freedom to choose the life he or she has reason to value (Sen, 2007). He further elaborates that these capabilities which include good health, education, social networks and command over economic resources will later influence decision-making that affects the citizens' life. Malaysian government in their $9^{\text {th }}$ Malaysia's Plan (2006) defines poverty as the lack of monetary ability to procure basic needs, which are measured by non-food and food based on actual expenditure of the bottom 20 percent expenditure group derived from the household expenditure survey. Malaysia had successfully reduced the incidence of poverty from 52.4 percent to 5.1 percent between 1970 and 2002. Total number of poor households had significantly fallen from 1.6 million to 267,000 over this period (Ahmad, 2005). Malaysia also has made great strides in eradicating poverty. Based on the latest figures of the $9^{\text {th }}$ Malaysian Plan Mid-term review, the overall hardcore poverty percentage is down to 0.7 percent, and only 3.6 percent of the Malaysian population is living below the overall poverty line.

By the country's fast economic growth and urbanization of the 1990's, the urban population swelled from 20 percent in 1960 to 40 percent in 1980 and to 60 percent in 2000 (World Bank, 2007). According to the United Nations Population Division, 78 percent of the country's population will be urbanized by 2030. The acceleration of urbanization has been accompanied by increase of urban poverty together with crowding, uneven distribution of development benefits and change in the ecology of urban environment (Mok, Gan \& Sanyal, 2007). Four mega cities in Malaysia in which consist of Kuala Lumpur, Johor Bahru, Penang as well as Kuching have experienced exponential growth in population as people throughout the countries have flocked to the cities to seek employment.

As the employment issues grew in urban area, social entrepreneurship organization is expected to play the role of 
change agents in the social sector (Dees, 2003). Marrioti and Glackin (2013) believe that social entrepreneurship is a for-profit enterprise that has the dual goals of achieving profitability and attaining beneficial social returns. Rather than the usual entrepreneurship organization, social entrepreneurship is looked into as ray of hope to help those below the poverty line to live a better life in the future. The effectiveness of such social entrepreneurship in achieving the organization's goals and their efficiency in their financing will further enhance their impact towards eradicating urban poverty.

In an article 'Varsities Urged (2003)' by Ha (2010), he viewed social entrepreneurship in Malaysia as still trying to gain momentum. Therefore, this research will helps scholars and practitioners to examine the effectiveness of "social" entrepreneurship in overcoming urban poverty in the country. In seeking to clarify the stated issue it is organized as follows: First, summary of literature on the concept of Urban Poverty, Social Entrepreneurship and Organizational Effectiveness is thoroughly discussed. Second, problem statement of the research is presented. Third, research's methodology and samples are both described. Fourth, the proposed conceptual framework is highlighted. Finally, the conclusion is provided by summarizing the avenue for future finding.

\section{Literature Review}

\subsection{The Underlying Theory of Social Entrepreneurship}

Social entrepreneurship combines the passion of a social mission with an image of business-like discipline, innovation, and determination. Owing to this dual-targeted nature, social entrepreneurship often has to exist between three common sectors: non-profit, for-profit and governmental (Pärenson, 2011). There were various researches done pertaining to social entrepreneurship and considerable debates have occurred over the definition of social entrepreneurship (Martin \& Osberg, 2007). Dees (2001) provided the key ideas about social entrepreneurship by believing that it involves pursuing highly innovative approaches to addressing social problems and doing so in an opportunistic, persistent, and accountable manner. Innovative approaches are typically pursued by non-profits or NGOs, but they can also be launched by for-profits or government agencies.

Based on existing research in social organizational management, economics and strategic management, Scott Helm (2007) developed a conceptualization of social entrepreneurship grounded in the realities of the social sector. He states that social entrepreneurship is the catalytic behaviour of non-profit organizations that engenders value and change in the sector, community or industry through the combination of innovation, risk-taking, and proactiveness. In addition to that, he also constructed and tested a scale to measure social entrepreneurship. Hence, the author uses the common themes of social entrepreneurship to formulate his theory. The theory concludes that a social entrepreneurship can be considered effective if it contain these features which are: innovation, risk-taking, and proactiveness.

\subsection{Organizational Effectiveness}

Organizational effectiveness is the ability of an organization to effectively accomplish its goals and objectives as stated by Selden and Sowa (2004). During the symposium of the Academy of Management which occurred more than two decades ago the organization effectiveness models were argued and Cameron and Whetten (1996) had listed the models in their book. They are, goal model (organization's successful accomplishment of the goals), resource dependence model (organization's successful acquirement of needed resources), internal congruence model (organization's consistency in internal functioning without strain) and the last one is strategic constituency model (organization successfully satisfy strategic constituency). In addition to that Gandy et al. (2012) in their study had proved their hypothesis that organizational effectiveness has significant positive relationship with social entrepreneurship.

Therefore, based on the listed model, the main model studied by this paper are, Goal Model and Resource Dependence Model. These models along with Gandy et al. (2012) hypothesis is main guideline for this paper to find out how organizational effectiveness in social entrepreneurship can overcome urban poverty in Malaysia.

\subsection{Relationship between Social Entrepreneurship and Organizational Effectiveness}

Social entrepreneurship is a for-profit enterprise that has the dual goals of achieving profitability and attaining beneficial social returns (Dees J., 2001). Herman and Renz (2004) share the same believe that the effectiveness of social entrepreneurship should be seen as a construct of multiple variables just as it is in the profit seeking ventures.Therefore, because organizations often have multiple goals, a single factor is inadequate for measuring organizational effectiveness. Researchers agree that for social entrepreneurship organizations, two of the most important factors related to effectiveness are; how well the organization achieves its specific mission and how financially efficient it is in doing so (Duncan, 2007; Levy \& Brennan, 2006).

Research made by Gandy et al. (2012) support above stand by illustrating the existence of positive relationship 
between social entrepreneurship and organizational effectiveness. They conclude in their finding that, as social entrepreneurship behaviour increases, organizational effectiveness tends to increase as well. This positive relationship would help organizational leaders develop strategies and adopt practices that could potentially have a significant impact on outcomes and the ability of the organization to achieve its mission. The study further suggest that leaders may want to think about proactively seeking ways to implement programs, policies, and services before other organizations in the same field do. Leaders who push their organizations to find and develop new methods for delivering services, coordinating volunteers, raising money, and for accomplishing other related tasks will be more effective. Their organizations tend to standout and attract more financial support rather that social entrepreneurship that lacks in this aspect thus sometimes making it hard to address urban poverty issues.

\subsection{Impact of Social Entrepreneurship in Overcoming Urban Poverty}

As one of the developing country, Malaysia have no explicit or specific national policy which directly addressed problems of the poor in the existing urban area according to Siwar and Kasim (1997). Therefore, Sarif et. al., (2013) based on their study, believe that there is a dire need for social entrepreneurship to build up the society in the long run. But the lowest levels of social entrepreneurship seem to exist in Asian regions which of course include Malaysia. This is based on Social Entrepreneurship activity (SEA) prevalence in 49 countries by using the Global Entrepreneurship Monitor (GEM) by Lepoutre et.al (2011). The minimal number of social entrepreneurship for Asian is because Malaysian themselves are still new to the concept (Sarif et. al., 2013).

The Deputy Higher Education Minister of Malaysia claimed that using the social entrepreneurship concept, would benefit about 40 per cent of Malaysian from the low-income group (Ha, 2010). Although it has been an overlooked area in the past, acknowledging it might create confidence with regard to choice and usage of the available facilities among the social entrepreneurs. Universities should teach the social entrepreneurship concept as a topic in its management courses so that students would receive a greater challenge in preparing a more effective sales tactic, especially for the lower income group.

Reviewing the past relationship between social entrepreneurship and urban poverty has led to an assumption of the existence of positive relationship between them if the proper organizational effectiveness is implemented in the social entrepreneurship itself. The existence of the relationship will help to put a huge mark in eradicating the numbers of urban poverty in the country.

\section{Problem Statement}

Previous researches' findings had proved the effectiveness in social entrepreneurial organizations can give impact to urban poverty such as in Herman and Renz (2004); Gandy et al. (2012); Duncan (2007) and Levy and Brennan (2006). However in Malaysia, research to examine such relationship is still non-existence. Therefore, this study will try to explain how social entrepreneurship can overcome urban poverty through organizational effectiveness by the guidance of the following research objectives: 1) To overview the effectiveness of the social entrepreneurship initiatives that social entrepreneurs have pursued in solving urban poverty issues. 2) To determine whether social entrepreneurship initiative have intended impact on organizational effectiveness in the context of urban poverty. 3) To identify social entrepreneurship model in overcoming urban poverty that currently being practiced in Malaysia. 4) To propose a comprehensive plan of action (social entrepreneurship urban poverty based model) in Malaysia context.

\section{Research Methodology}

This study will be conducted through in-depth interviews (case study method). The methodological approach of case study will be used to collect the data and organise the research. Qualitatively, six case studies will be developed to capture the richness of data gathered by social entrepreneurs. The results of interviewing social entrepreneurs (government officials, intellectuals and corporate figures) will be presented in a variety of tables and boxes.

Although case study requires more resources and consumes more time, it has the advantage of enhancing the quality of the study and increasing its external validity. There are three types of case study notes by Yin (1984) which are exploratory, descriptive and explanatory. The case study for this research will be an explanatory type as it aims to examine closely both at a surface and deep level in order to explain the phenomenon of how organizatinal effectiveness can effect social entrepreneurship to overcome urban poverty.

Through this methodology, representatives from six social entrpreneurship organizations from the main urban areas in Malaysia will be invited to a one-hour face-to-face semi-structured, in-depth interviews. The method of interviewing social entrepreneurs, a number of government officials and intellectuals as well as corporate figures 
with special interest in social entrepreneurship will equip this research with a holistic perspective of the social entrepreneurship environment.

The interview question is constructed to explore the organizational effectiveness in each of the social entrepreneurship organization in eradicating urban poverty of the selected areas. In the beginning of the interview, the participant will answer questions about the organization's background and the financial information about the organization is requested by the interviewing team. Pictures and physical descriptions of the organization's office is also recorded in order to evaluate how effective the organization in organizing the environment of their office. In the later part of the interview, the questions will evolve around how well the organization at achieving their goals and how financially efficient they are in order to be a successful social entrepreneurship organization. All of the session will be digitally decoded by the interviewing team using a voice recorder.

The recorded inteview will be in form of MPEG-2 Audio Layer III (MP3) format. The data from the audio will be encoded according to the reasearch protocol. All of the similar outcomes from the interview will be used to create a proper conclusion for this study. Such outcome will later complete the final objective of the study which is to propose a comprehensive plan of action (social entrepreneurship - urban poverty based model) in Malaysia context.

\section{Rethinking Organizational Effectiveness through Social Entrepreneurship in Urban Poverty in Malaysia}

This study is conducted to examine the relationship between social entrepreneurship and organizational effectiveness in Malaysia. The past researches have proven that organizational effectiveness can give impact on social entrepreneurship in overcoming urban poverty. Thus these are the propositions:

Table 1. A propositional framework of the relationship between social entrepreneurship and organizational effectiveness

\begin{tabular}{ll}
\hline SOCIAL ENTREPRENEURSHIP & ORGANIZATIONAL EFFECTIVENESS \\
\hline Innovation & Mission Achievement \\
Proactiveness & Financial Efficiency \\
Risk-taking & \\
\hline
\end{tabular}

Proposition 1: Through innovation in social entrepreneurship, mission of the organization can be achieved to curb urban poverty;

Proposition 2: Through proactiveness in social entrepreneurship, mission of the organization can be achieved to curb urban poverty;

Proposition 3: Through risk-taking in social entrepreneurship, mission of the organization can be achieved to curb urban poverty;

Proposition 4: Innovation in social entrepreneurship requires financial efficiency to curb urban poverty;

Proposition 5: Proactiveness in social entrepreneurship requires financial efficiency to curb urban poverty;

Proposition 6: Risk-taking in social entrepreneurship requires financial efficiency to curb urban poverty.

\section{Conclusion}

This study attempts to contribute a small piece of evidence that the relationship between social entrepreneurship and organizational effectiveness will give a positive resolution to urban poverty in Malaysia. The outcome of this study will help to change the mindset of targeted urban poverty under study so that they become more positive towards social entrepreneurship in Malaysia. This study is also expected to be useful for social entrepreneurship organization to help those who live below the line of poverty to enhance their income and upgrade their entrepreneurship strategies through the understanding of organizational effectiveness.

\section{References}

Ahmad, N. (2005). The Role of Government in Poverty Reduction. Paper presented at National Seminar on Poverty Eradication through Empowerment, Kuala Lumpur, Aug 23.

Ashoka. (2006). Leading Social Entrepreneurs. Arlington, VA: Ashoka. 
Cameron, K. S., \& Whetten, D. A. (1996). Higher Education; Handbook of Theory and Research. New York: Agathon Press.

Committee on Poverty Reduction, Economic and Social Commission for Asia and the Pacific. (2007). Urban Poverty and the Working Poor: Facing the Challenges of Urbanization and Urban Poverty in Asia and the Pacific. Fourth session, Bangkok.

Dees, J. G. (2001). The Meaning of Social Entrepreneurship. Working Paper, Fuqua School of Business, Duke University.

Duncan, E. (2007). A Grounded Theory Study On Social Entrepreneurship (Doctoral dissertation). ProQuest Dissertations \& Theses database (UMI No. 3338361).

Gandy, J. D. et al. (2012). The Relationship between Social Entrepreneurship and Organizational Effectiveness. ProQuest Dissertations \& Theses Database (UMI No. 3547013).

Ha, Z. Z. (2010, April, 10). Varsities Urged To Pioneer Social Entrepreneurship. Bernama. Retrieved from http://blis2.bernama.com.libproxy.unisza.edu.my/mainHomeBypass.do

Helm, S. (2007). Social Entrepreneurship: Defining the Non-Profit Behaviour and Creating an Instrument for Measurement (Doctoral dissertation). ProQuest Dissertations \& Theses database (UMI No. 3265545).

Herman, R. D., \& Renz, D. O. (2004). Doing Things Right: Effectiveness in Local Non-Profit Organizations, A $\begin{array}{lllll}\text { Panel Study. Public Administration } & \text { Review, 64(6), }\end{array}$ http://dx.doi.org/10.1111/j.1540-6210.2004.00416.x

Hoogendoorn, B. (2011). Social Entrepreneurship in the Modern Economy: Warm Glow, Cold Feet. Doctor of Philosophy Dissertation, Erasmus Research Institute of Management - ERIM, Erasmus University Rotterdam.

Lepoutre, J., Justo, R., Terjesen, S., \& Bosma, N. S. (2011). Designing a Global Standardized Methodology for Measuring Social Entrepreneurship Activity: The Global Entrepreneurship Monitor Social Entrepreneurship Study. Small Business Economics.

Levy, D., \& Brennan, K. (2006).How do you measure social impact? Social Edge. Retrieved from http://www.socialedge.org/discussions/success-metrics/measuringsocial-impact/

Malaysia. (2006). Ninth Malaysia Plan, 2006-2010. Economic Planning Unit, Government Printer, Putrajaya.

Mariotti, S., \& Glackin, C. (2013). Entrepreneurship Starting and Operating a Small Business. New Jersey: Pearson Education.

Martin, R. L., \& Osberg, S. (2007). Social entrepreneurship: The case for definition. Stanford Social Innovation Review. Stanford University.

Mok, T. Y., Gan, S., \& Sanyal, A. (2007). The Determinants of Urban Household Poverty in Malaysia. Journal of Social Sciences, 3(4), 190-196. http://dx.doi.org/10.3844/jssp.2007.190.196

Pa"Renson, T. (2011). The Criteria for a Solid Impact Evaluation in Social Entrepreneurship. Society and Business Review, 9. http://dx.doi.org/10.1108/17465681111105823

Sarif, S. M., Ismail, Y., \& Sarwar, A. (2013). Creating Wealth through Social Entrepreneurship: A Case Study from Malaysia. Journal of Basic and http://dx.doi.org/349-350.10.5829/idosi.mejsr.2013.14.11.2347

Selden, S. C., \& Sowa, J. E. (2004). Testing a multi-dimensional model of organizational performance: Prospects and problems. Journal of Public Administration Researchand Theory, 14(3). http://dx.doi.org/10.1093/jopart/muh025

Siwar, C., \& Kasim, M. Y. (1997). Urban Development and Urban Poverty in Malaysia. International Journal of Social Economics, 24(12), 158. http://dx.doi.org/10.1108/03068299710193958

World Bank. (2007). East Asia 10 Years after the Financial Crisis. Washington DC.

Yin, R. K. (1984). Case Study Research: Design and Methods. Beverly Hills, CA: Sage Publicatiom. 


\section{Copyrights}

Copyright for this article is retained by the author(s), with first publication rights granted to the journal.

This is an open-access article distributed under the terms and conditions of the Creative Commons Attribution license (http://creativecommons.org/licenses/by/3.0/). 